\title{
Austrodiplostomum compactum metacercariae (Digenea: Diplostomidae) in Schizodon intermedius (Characiformes: Anostomidae) from Jurumirim reservoir, Brazil
}

\author{
Metacercárias de Austrodiplostomum compactum (Digenea: Diplostomidae) em Schizodon intermedius \\ (Characiformes: Anostomidade) do reservatório de Jurumirim, Brasil \\ Igor Paiva Ramos ${ }^{1,2 *}$; Lidiane Franceschini ${ }^{3}$; Aline Cristina Zago ${ }^{3}$; Érica de Oliveira Penha Zica \\ Alison Carlos Wunderlich ${ }^{3}$; Felipe Pontieri de Lima ${ }^{3}$; Reinaldo José da Silva ${ }^{3}$

\begin{abstract}
${ }^{1}$ Departamento de Biologia e Zootecnia, Faculdade de Engenharia de Ilha Solteira, Universidade Estadual Paulista - UNESP, Ilha Solteira, SP, Brasil - UNESP, Botucatu, SP, Brasil

${ }^{3}$ Departamento de Parasitologia, Laboratório de Parasitologia de Animais Silvestres, Instituto de Biociências, Universidade Estadual Paulista - UNESP, Botucatu, SP, Brasil
\end{abstract} \\ ${ }^{2}$ Departamento de Morfologia, Laboratório de Biologia e Ecologia de Peixes, Instituto de Biociências, Universidade Estadual Paulista
}

Received August 10, 2015

Accepted September 14, 2015

\begin{abstract}
This study reports the occurrence of Austrodiplostomum compactum metacercariae in the freshwater fish Schizodon intermedius (ximborê/piava) from a Neotropical reservoir in the Paranapanema River, state of São Paulo, Brazil. From a total of 75 fish collected, we found 38 infected with $A$. compactum metacercariae (prevalence $=50.67 \%$ ) in the eyes. The mean intensity of infection and mean abundance were $9.05 \pm 4.26(1-155)$ and $4.59 \pm 2.20(0-155)$, respectively. Poulin's Discrepancy Index was 0.87 and four specimens presented more than 10 metacercariae in their eyes. No correlation was observed between parasite abundance and standard length, total weight and condition factor ( $p>0.05)$. These metacercariae are reported for the first time in S. intermedius.
\end{abstract}

Keywords: Freshwater fish, eyefluke, ximborê, Paranapanema River, Paraná River basin.

\section{Resumo}

Este estudo reporta a ocorrência de metacercárias de Austrodiplostomum compactum na espécie de peixe de água doce Schizodon intermedius (ximborê/piava), oriunda de um reservatório Neotropical no rio Paranapanema, Estado de São Paulo, Brasil. Um total de 75 peixes foram coletados, sendo que 38 estavam infectados com metacercárias de A. compactum (prevalência $=50,67 \%$ ) nos olhos. A intensidade média de infecção e abundância média foram 9,05 $\pm 4,26$ (1-155) e 4,59 \pm 2,20 (0-155), respectivamente. O Índice de Discrepância de Poulin foi de 0,87, e quatro exemplares apresentaram mais do que 10 metacercárias em seus olhos. Não foram observadas correlação entre abundância média e comprimento padrão, peso total e fator de condição $(\mathrm{p}>0,05)$. Esse é o primeiro registro dessa espécie de metacercária para $S$. intermedius.

Palavras-chave: Peixe de água doce, trematódeo parasita de olho, ximborê, rio Paranapanema, bacia do rio Paraná.

\footnotetext{
*Corresponding author: Igor Paiva Ramos. Departamento de Biologia e Zootecnia, Faculdade de Engenharia de Ilha Solteira, Universidade Estadual Paulista - UNESP, Campus de Ilha Solteira, CEP 15385-000, Ilha Solteira, SP, Brasil. e-mail: igor.paiva.ramos@gmail.com
} 
Metacercariae of diplostomids are widely distributed in the Neotropical region, and have a life cycle with three hosts: a snail (first intermediate host); a fish (second intermediate host) or, rarely, an amphibian (paratenic host); and a piscivorous bird as the definitive host (KARVONEN et al., 2006; VIOLANTEGONZÁLEZ et al., 2009). Adults of diplostomids release their eggs into water via the feces of infected piscivorous birds, and hatching of free-swimming larva (miracidia) can occur up to 22 days later, depending on the water temperature (GROBBELAAR et al., 2014). In Brazil, miracidium actively infect aquatic snails of the genus Biomphalaria Preston, 1910 (PINTO \& MELO, 2013), and polyembriony occurs in the digestive gland and liver of snails (CROWDEN \& BROOM, 1980; HOFFMAN \& HUNDLEY, 1957). Infected snails release cercariae, which actively infect fish (second intermediate host), preferentially through their gills and mouth (HAAS et al., 2007), although penetration may also occur through their fins and body surface (GROBBELAAR et al., 2014).

In fish, the parasites develop to the metacercariae, which generally parasitize the eyes (SEPPÄLÄ et al., 2004) and brain (GROBBELAAR et al., 2014). The adult/reproductive form of this parasite species is found in the digestive system of piscivorous birds, when these birds feed on infected fish. Neotropical cormorants, Phalacrocorax brasilianus (Gmelin, 1789), which are a widespread generalist species, are considered to be the definitive host of this diplostomid in Brazil (MONTEIRO et al., 2011).

According to Grobbelaar et al. (2014), the life cycle of diplostomids depends on predation by piscivorous birds and exposure of susceptible fish and snail species to the larval stages (cercariae and miracidium, respectively). Thus, the effects relating to loss of vision in fish with high rates of infection can contribute towards predation and facilitate transmission of the parasite to the definitive hosts (SEPPÄLÄ et al., 2004).

Austrodiplostomum compactum (Lutz, 1928) metacercariae have been reported in 36 species of Brazilian freshwater fish (MARTINS et al., 2002; SANTOS et al., 2012; RAMOS et al., 2013). However, considering that Brazilian fish richness is estimated to comprise 2,587 species (BUCKUP et al., 2007), the number of fish species that have been evaluated with regard to infection with $A$. compactum metacercariae is very low. This study reports occurrences of $A$. compactum metacercariae in Schizodon intermedius Garavello \& Britski, 1990, an omnivorous Brazilian fish species, from the Jurumirim reservoir, Paranapanema River, Brazil.

This study was conducted in the Jurumirim reservoir (upper Paranapanema River; 2319'38.8” S, 48044’02.04” W), in the municipality of Angatuba, State of São Paulo, Brazil (Figure 1).

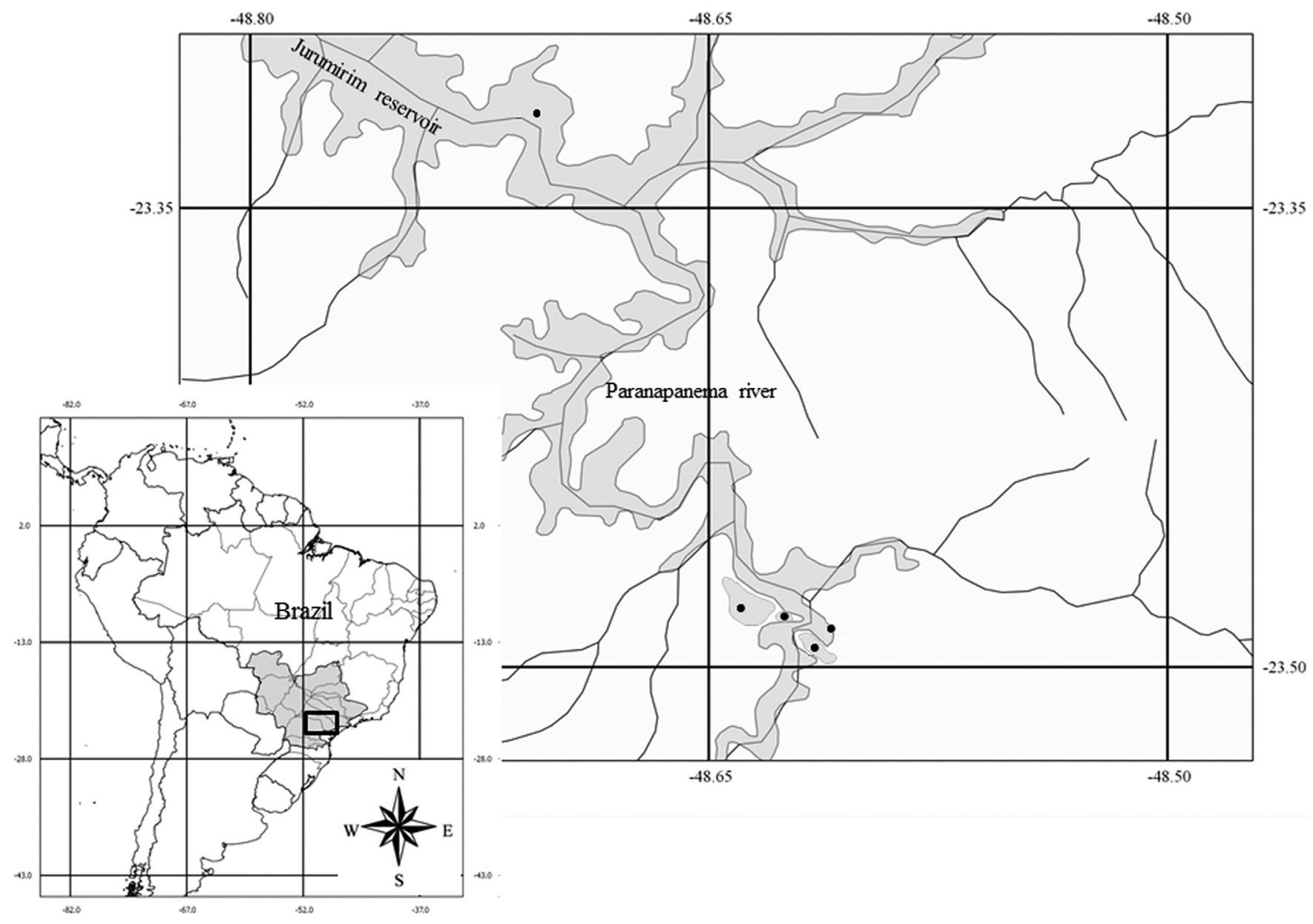

Figure 1. Jurumirim reservoir (upper Paranapanema River, state of São Paulo), indicating the five sampling stretches $(\bullet)$. 
Fish were collected between January 2010 and February 2011 using gillnets (mesh size of 3 to $14 \mathrm{~cm}$ between adjacent knots) that were set for 14 hours overnight (from 5:00 PM to 7:00 AM) according to ICMBio authorization no 15549-1. Seventy-five fish were collected, frozen and transported to the laboratory, where they were weighed (total weight in grams ( $\mathrm{g}$ ) of the fish with viscera) and measured (standard length in centimeters $(\mathrm{cm})$ measured from tip of the snout to the last vertebra). The eyes were removed and examined using a stereomicroscope. Metacercariae were collected from the vitreous humor, fixed in $70 \%$ alcohol under cover slip pressure and preserved in 70\% alcohol (EIRAS et al., 2006). The metacercariae were stained with carmine and cleared with eugenol for further identification under a differential interference contrast microscope (Leica DM 5000B). Morphological analyses were performed using a computerized system for image analysis (LAS V3 - Leica Application Suite, Wetzlar, Germany).

The prevalence, mean intensity of infection and mean abundance were calculated in accordance with Bush et al. (1997). The condition factor was calculated as described by Vazzoler (1996) and Poulin's Discrepancy Index (POULIN, 1993; 1996) was calculated using the Quantitative Parasitology 3.0 software program (REICZIGEL \& RÓZSA, 2005. The Spearman correlation test was used to evaluate possible correlations between the total weight, standard length and condition factor of the fish and the mean abundance of metacercariae. The significance level used was $\mathrm{p}<0.05$ and all statistical tests were performed using the open access software Bioestat 5.0 .

Parasite and host voucher specimens were deposited in the Helminthological Collection of the Department of Parasitology (CHIBB 7480 until 7513) and the Collection of the Fish Biology and Genetics Laboratory (LBP 13311), respectively, in the Institute of Biosciences, Universidade Estadual Paulista (UNESP), municipality of Botucatu, state of São Paulo, Brazil.

Seventy-five specimens of $S$. intermedius were collected and presented total weight mean of $135.20 \pm 6.91 \mathrm{~g}$ (range: $19.40-271.43 \mathrm{~g}$ ), mean standard length of $18.03 \pm 0.34 \mathrm{~cm}$ (range: $10.00-25.00 \mathrm{~cm}$ ) and mean condition factor of $2.22 \pm 0.03$ (range: 1.49-3.10).

Three hundred and forty-four $A$. compactum metacercariae were recovered from 38 fish specimens infected (Prevalence $[\mathrm{P}]=50.67 \%$ ). The mean intensity of infection was $9.05 \pm 4.26$ (range: $1-155$ ), mean abundance was $4.59 \pm 2.20$ (range: $0-155$ ) and Poulin's Discrepancy Index was 0.87 . Four specimens presented more than 10 metacercariae in their eyes $(18,28,56$ and 155 metacercariae, respectively). The mean intensity of infection did not show correlation with weight $(\mathrm{p}=0.10$ and $\mathrm{rs}=-0.26)$ and length $(\mathrm{p}=0.43$ and $r s=-0.13$ ). For condition factor, the Spearman's correlation coefficient was positive but low $(p=0.002$ and $r s=-0.46)$. At same way, the mean abundance also did not show correlation with weight ( $\mathrm{p}=0.11$ and $\mathrm{rs}=-0.18)$ and length $(\mathrm{p}=0.53$ and $\mathrm{rs}=-0.07)$ and for the condition factor the Spearman's correlation coefficient was positive and low ( $\mathrm{p}=0.03$ and $\mathrm{rs}=-0.24)$.

Austrodiplostomum compactum metacercariae have been recorded in a wide variety of Brazilian fishes. The number of Brazilian fish species infected by $A$. compactum, including this record, has now increased to 37. These results corroborate the observations of Yamada et al. (2008), who hypothesized that the larval stage of the parasite species has low specificity for the second intermediate host (fish). According to Ramos et al. (2013), the majority of fish species infected with $A$. compactum metacercariae in Brazil belong to the orders Perciformes (12 species), Siluriformes (13 species) and Characiformes (nine species), and to the families Cichlidae (10 species) and Loricariidae (eight species). Moreover, with the record of the present study, the number of fish species infected with metacercariae of $A$. compactum in the order Characiformes has now increased to 10 .

The mean intensity of infection among the fish analyzed here was similar to what was observed by Karvonen et al. (2004), who reported that their fish harbored approximately 10 Diplostomum spathaceum metacercariae in their eyes, with up to $49 \%$ cataract coverage. In addition, high rates of infection with diplostomid metacercariae in fish can cause blindness or visual impairment (EIRAS, 1994), cataracts (SHARIFF et al., 1980; KARVONEN et al., 2004), problems with food intake and growth (OWEN et al., 1993) and increased susceptibility to predation (CROWDEN \& BROOM, 1980; SEPPÄLÄ et al., 2004). The high value of Poulin's Discrepancy Index showed high aggregation for this parasite in $S$. intermedius and demonstrated that some individuals presented high rates of infection. Thus, the population of $S$. intermedius evaluated did not present mean intensity of infection compatible with serious damage, as reported above. However, some specimens may have been experiencing problems relating to presence of A. compactum metacercariae, due to the intensity of infection.

\section{Acknowledgements}

The authors are grateful to the Institute of Biosciences of Botucatu (IBB) - Universidade Estadual Paulista "Júlio de Mesquita Filho" - UNESP, for the use of laboratory facilities and logistics and Prof. Adj. Edmir Daniel Carvalho (in memorian) for the contribution during the execution of this work. This study complies with current Brazilian laws. This study was supported by FAPESP (Fundação de Amparo à Pesquisa do Estado de São Paulo - process number 2010/19543-6).

\section{References}

Buckup PA, Menezes NA, Ghazzi MS. Catálogo das espécies de peixes de água doce do Brasil. Rio de Janeiro: Museu Nacional; 2007.

Bush AO, Lafferty KD, Lotz JM, Shostak AW. Parasitology meets ecology on its own terms: Margolis et al. revisited. J Parasitol 1997; 83(4): 575583. http://dx.doi.org/10.2307/3284227. PMid:9267395.

Crowden AE, Broom DM. Effects of the eyefluke, Diplostomum spathaceum, on the behaviour of dace (Leuciscus leuciscus). Anim Behav 1980; 28(1): 287-294. http://dx.doi.org/10.1016/S0003-3472(80)80031-5.

Eiras JC, Takemoto RM, Pavanelli GC. Métodos de estudo e técnicas laboratoriais em parasitologia de peixes. 2nd ed. Maringá: Eduem; 2006.

Eiras JC. Elementos de ictioparasitologia. Porto: Fundação Engenheiro Antônio de Almeida; 1994.

Grobbelaar A, Van As LL, Butler HJB, Van As JG. Ecology of diplostomid (Trematoda: Digenea) infection in freshwater fish in southern Africa. $A f r$ Zool 2014; 49(2): 222-232. http://dx.doi.org/10.3377/004.049.0206.

Haas W, Wulff C, Grabe K, Meyer V, Haeberlein S. Navigation within host tissues: cues for orientation of Diplostomum spathaceum (Trematoda) 
in fish towards veins, head and eye. Parasitology 2007; 134(Pt 7): 10131023. http://dx.doi.org/10.1017/S0031182007002430. PMid:17316474.

Hoffman GL, Hundley JB. The life-cycle of Diplostomum baeri eucaliae n. subsp. (Trematoda: Strigeida). J Parasitol 1957; 43(6): 613-627. http:// dx.doi.org/10.2307/3286550. PMid:13492114.

Karvonen A, Savolainen M, Seppälä O, Valtonen ET. Dynamics of Diplostomum spathaceum infection in snail hosts at a fish farm. Parasitol Res 2006; 99(4): 341-345. http://dx.doi.org/10.1007/s00436-006-01378. PMid: 16565817.

Karvonen A, Seppälä O, Valtonen ET. Eye fluke-induced cataract formation in fish: quantitative analysis using an ophthalmological microscope. Parasitology 2004; 129(4): 473-478. http://dx.doi.org/10.1017/ S0031182004006006. PMid:15521636.

Martins ML, Paiva AMFC, Fujimoto RY, Schalch SHC, Colombano NC. Prevalência, sazonalidade e intensidade de infecção por Diplostomum (Austrodiplostomum) compactum Lutz, 1928 (Digenea, Diplostomidae), em peixes do reservatório de Volta Grande, Estado de Minas Gerais, Brasil. Acta Sci Biol Sci 2002; 24(2): 469-474.

Monteiro CM, Amato JFR, Amato SB. Helminth parasitism in the Neotropical cormorant, Phalacrocorax brasilianus, in Southern Brazil: effect of host size, weight, sex, and maturity state. Parasitol Res 2011; 109(3): 849-855. http://dx.doi.org/10.1007/s00436-011-2311-x. PMid:21431903.

Owen SF, Barber I, Hart PJB. Low level infection by eye fluke, Diplostomum spp., affects the vision of three-spined sticklebacks, Gasterosteus aculeatus. J Fish Biol 1993; 42(5): 803-806. http://dx.doi. org/10.1111/j.1095-8649.1993.tb00387.x.

Pinto HA, Melo AL. Biomphalaria straminea and Biomphalaria glabrata (Mollusca: Planorbidae) as new intermediate hosts of the fish eyefluke Austrodiplostomum compactum (Trematoda: Diplostomidae) in Brazil. J Parasitol 2013; 99(4): 729-733. http://dx.doi.org/10.1645/12-13.1. PMid:23360402.

Poulin R. Measuring parasite aggregation: defending the index of discrepancy. Int J Parasitol 1996; 26(2): 227-229. http://dx.doi.org/10.1016/00207519(95)00117-4. PMid:8690549.
Poulin R. The disparity between observed and uniform distributions: a new look at parasite aggregation. Int J Parasitol 1993; 23(7): 937-944. http://dx.doi.org/10.1016/0020-7519(93)90060-C. PMid:8106186.

Ramos IP, Francheschini L, Zago AC, Zica EOP, Wunderlich AC, Carvalho ED, et al. New host records and a checklist of fishes infected with Austrodiplostomum compactum (Digenea: Diplostomidae) in Brazil. Rev Bras Parasitol Vet 2013; 22(4): 511-518. http://dx.doi.org/10.1590/ S1984-29612013000400010. PMid:24473875.

Reiczigel J, Rózsa L. Quantitative parasitology 3.0 [online]. Budapest; 2005 [cited 2015 Jun 24]. Available from: http://www.zoologia.hu/qp/qp.html

Santos RS, Marchiori N, Santarem VA, Takahashi HK, Mourino JLP, Martins ML. Austrodiplostomum compactum (Lutz, 1928) (Digenea, Diplostomidae) in the eyes of fishes from Paraná River, Brazil. Acta Sci Biol Sci 2012; 34(2): 225-231. http://dx.doi.org/10.4025/actascibiolsci. v34i2.9337.

Seppälä O, Karvonen A, Valtonen ET. Parasite-induced change in host behaviour and susceptibility to predation in an eye fluke-fish interaction. Anim Behav 2004; 68(2): 257-263. http://dx.doi.org/10.1016/j. anbehav.2003.10.021.

Shariff M, Richards RH, Sommerville C. The histopathology of acute and chronic infections of rainbow trout Salmo gairdneri Richardson with eye flukes, Diplostomum spp. J Fish Dis 1980; 3(6): 455-465. http://dx.doi. org/10.1111/j.1365-2761.1980.tb00432.x.

Vazzoler AEA. Biologia da reproduçâo de peixes teleósteos: teoria e prática. Maringá: Eduem; 1996.

Violante-González J, García-Varela M, Rojas-Herrera A, Guerrero SG. Diplostomiasis in cultured and wild tilapia Oreochromis niloticus in Guerrero State, Mexico. Parasitol Res 2009; 105(3): 803-807. http:// dx.doi.org/10.1007/s00436-009-1458-1. PMid:19452167.

Yamada FH, Moreira LHA, Ceschini TL, Takemoto RM, Pavanelli GC. Novas ocorrências de metacercária de Austrodiplostomum compactum (Lutz, 1928) (Platyhelminthes: Digenea) parasito de olhos de peixes da bacia do rio Paraná. Rev Bras Parasitol Vet 2008; 17(3): 163-166. http:// dx.doi.org/10.1590/S1984-29612008000300010. PMid:19245765. 